A COMPARATIVE STUDY

\title{
Ellipticine and benzo(a)pyrene increase their own metabolic activation via modulation of expression and enzymatic activity of cytochromes P450 1A1 and 1A2
}

\author{
Dagmar AIMOVÁ 1, Jitka POLJAKOVÁ 1, Věra KOTRBOVÁ 1, Michaela MOSEROVÁ 1, \\ Eva FREI ${ }^{2}$, Volker M. ARLT ${ }^{3}$, Marie STIBOROVÁ 1 \\ 1 Department of Biochemistry, Faculty of Science, Charles University, Prague, Albertov 2030, 12840 Prague 2, CZECH REPUBLIC \\ 2 Division of Molecular Toxicology, German Cancer Research Center, Im Neuenheimer Feld 280, 69120 Heidelberg, GERMANY \\ 3 Section of Molecular Carcinogenesis, Institute of Cancer Research, Brookes Lawley Building, Sutton, Surrey SM2 5NG, UNITED KINGDOM
}

ITX010208A04 • Received:4 July 2008 • Revised: 7 August 2008 • Accepted: 18 August 2008 • Electronic Publication: November 2010

\begin{abstract}
Two compounds known to covalently bind to DNA after their activation with cytochromes P450 (CYPs), carcinogenic benzo(a)pyrene $(\mathrm{BaP})$ and an antineoplastic agent ellipticine, were investigated for their potential to induce CYP and NADPH:CYP reductase (POR) enzymes in rodent livers, the main target organ for DNA adduct formation. Two animal models were used in the study: (i) rats as animals mimicking the fate of ellipticine in humans and (ii) mice, especially wild-type (WT) and hepatic POR null (HRN ${ }^{\mathrm{TM}}$ ) mouse lines. Ellipticine and BaP induce expression of CYP1A enzymes in livers of experimental models, which leads to increase in their enzymatic activity. In addition, both compounds are capable of generating DNA adducts, predominantly in livers of studied organisms. As determined by ${ }^{32} \mathrm{P}$ postlabelling analysis, levels of ellipticine-derived DNA adducts formed in vivo in the livers of HRN ${ }^{\mathrm{TM}}$ mice were reduced (by up to 65\%) relative to levels in WT mice, indicating that POR mediated CYP enzyme activity is important for the activation of ellipticine. In contrast to these results, 6.4 fold higher DNA binding of BaP was observed in the livers of HRN ${ }^{\mathrm{TM}}$ mice than in WT mice. This finding suggests a detoxication role of CYP1A in BaP metabolism in vivo. In in vitro experiments, DNA adduct formation in calf thymus DNA was up to 25 fold higher in incubations of ellipticine or BaP with microsomes from pretreated animals than with controls. This stimulation effect was attributed to induction of CYP1A1/2 enzymes, which are responsible for oxidative activation of both compounds to the metabolites generating major DNA adducts in vitro. Taken together, these results demonstrate that by inducing CYP1A1/2, ellipticine and BaP modulate their own enzymatic metabolic activation and detoxication, thereby modulating their either pharmacological (ellipticine) and/or genotoxic potential (both compounds).
\end{abstract}

KEY WORDS: benzo(a)pyrene; ellipticine; induction; cytochromes P450; NADPH:cytochrome P450 reductase; HRNM mice

\section{Introduction}

Ellipticine and benzo[a]pyrene $(\mathrm{BaP})$ are compounds exhibiting significant biological activities. Ellipticine is an efficient anticancer agent (for a summary, see Stiborová et al., 2006b), while BaP is a strong carcinogen (for a summary, see Arlt et al., 2008). Therefore, both two compounds were employed by us for studies concerning their phatmacological and toxicological effects.

\section{Correspondence address:}

\section{Prof Marie Stiborová, DrSc.}

Department of Biochemistry, Faculty of Science, Charles University, Prague, Albertov 2030, 12840 Prague 2, Czech Republic

E-MAll: stiborov@natur.cuni.cz
Ellipticine, an alkaloid isolated from Apocyanaceae plants, and its derivatives exhibits significant antitumor and anti-HIV activities, characterized by high efficiencies against several types of cancer and rather limited toxic side effects, including complete lack of hematological toxicity. Nevertheless, ellipticines are potent mutagens. Several mechanisms of their antitumor, mutagenic and cytotoxic activities have been hitherto suggested: (i) intercalation into DNA; (ii) inhibition of DNA topoisomerase II activity; (iii) selective inhibition of p53 protein phosphorylation; (iv) disruption of the energy balance of cells by uncoupling mitochondrial oxidative phosphorylation (for a summary, see Stiborová et al., 2001; 2006b). Recently, we have shown that ellipticine also binds covalently to DNA in vitro and in vivo, after being enzymatically activated with cytochromes 
P450 (CYP) (Figure 1) or peroxidases, suggesting a third possible mechanism of action (Stiborová et al., 2001; 2003a,b; 2004; 2007a).

On the basis of in vitro studies, human and rat CYPs of $1 \mathrm{~A}$ and $3 \mathrm{~A}$ subfamilies seem to be the predominant enzymes oxidizing ellipticine either to metabolites that are excreted (7- or 9-hydroxyellipticine) or form DNA adducts (12-or 13-hydroxy-ellipticine) (Stiborová et al., 2001; 2003b; 2004; 2006; Kotrbová et al., 2006). Besides these CYPs, peroxidases such as mammalian cyclooxygenases (COX-1 and -2), lactoperoxidase and myeloperoxidase, efficiently generate the same ellipticine-derived DNA adducts in vitro (Stiborová et al., 2007a; Poljaková et al., 2006). Identical DNA adducts were also detected in cells in culture, in which both CYPs and peroxidases are expressed, such as human breast adenocarcinoma MCF-7 cells (Bořek-Dohalská et al., 2004), leukemia HL-60 and CCRF-CEM cells (Poljaková et al., 2007) and V79 Chinese hamster lung fibroblasts transfected with human CYP3A4, 1A1 and 1A2 (Frei et al., 2002). After i.p. administration of ellipticine, the ellipticine-DNA adduct levels seem to be related to CYP3A1 and 1A content in different tissues of rat, but the real impact of CYPs or peroxidases in this process could not be still exactly evaluated (Stiborová et al., 2003a, 2007b).

$\mathrm{BaP}$, as the second model compound in this comparative study is, similarly to the other polycyclic aromatic hydrocarbons (PAHs), mutagenic and carcinogenic (IARC, 1983; Phillips 1999, 2002). PAHs are produced mainly by incomplete combustion or pyrolysis of organic matter and are ubiquitous in the environment, leading to measurable background levels of exposure in the general population (IARC, 1983). Beside the inhalation of polluted air, the main routes of exposure are through tobacco smoke, diet (Phillips 1999,
2002) and occupational exposition throughout e.g. coal, coke or coal-tar processing and use of coal-tar products (IARC, 1983). Prior to the reaction with DNA, BaP analogously to ellipticine requires metabolic activation (Figure 2), which is an essential step in the mechanism by which $\mathrm{BaP}$ exerts its genotoxic effects. CYP1A1 and CYP1B1 are widely accepted to be the most important enzymes in the metabolic activation of BaP (Baird et al., 2005). However, current studies show that BaP-induced DNA damage was increased in mice lacking CYP1A1, indicating that in vivo the CYP1A1 enzyme plays a detoxification role, and protects mice against $\mathrm{BaP}$ toxicity (Uno et al., 2004, 2006). PAHs affect the expression of numerous enzymes involved in metabolism of xenobiotics (including CYP1A1) mainly via the aromatic hydrocarbon receptor (AhR). AhR-dependent inducibility was correlated to the predisposion to some types of cancer (Kouri et al., 1973).

The detailed knowledge on the role of CYP enzymes in activation and/or detoxication of $\mathrm{BaP}$ and ellipticine and that on their induction mediated by these xenobiotics, is crucial for the possibility to modify their carcinogenic and/or the therapeutic efficiency. Therefore, this field was extensively investigated in our laboratory. To investigate the real role of CYPs in metabolism of both compounds, we have used several animal models, such as rats, rabbits and/or mice in our previous studies (Stiborová et al., 2001; 2003a; b; 2004; 2006; 2007b; 2008; Kotrbová et al., 2006; Arlt et al., 2008). In the case of mice, the $\mathrm{HRN}^{\mathrm{sm}}$ (Hepatic Cytochrome P450 Reductase Null) mice, the mouse line lacking the hepatic NADPH:CYP oxidoreductase (POR), the unique electron donor to CYPs, which results in the loss of essentially all hepatic CYP function (Henderson et al., 2003, 2006), was utilized (Stiborová et al., 2008; Arlt et al., 2008).

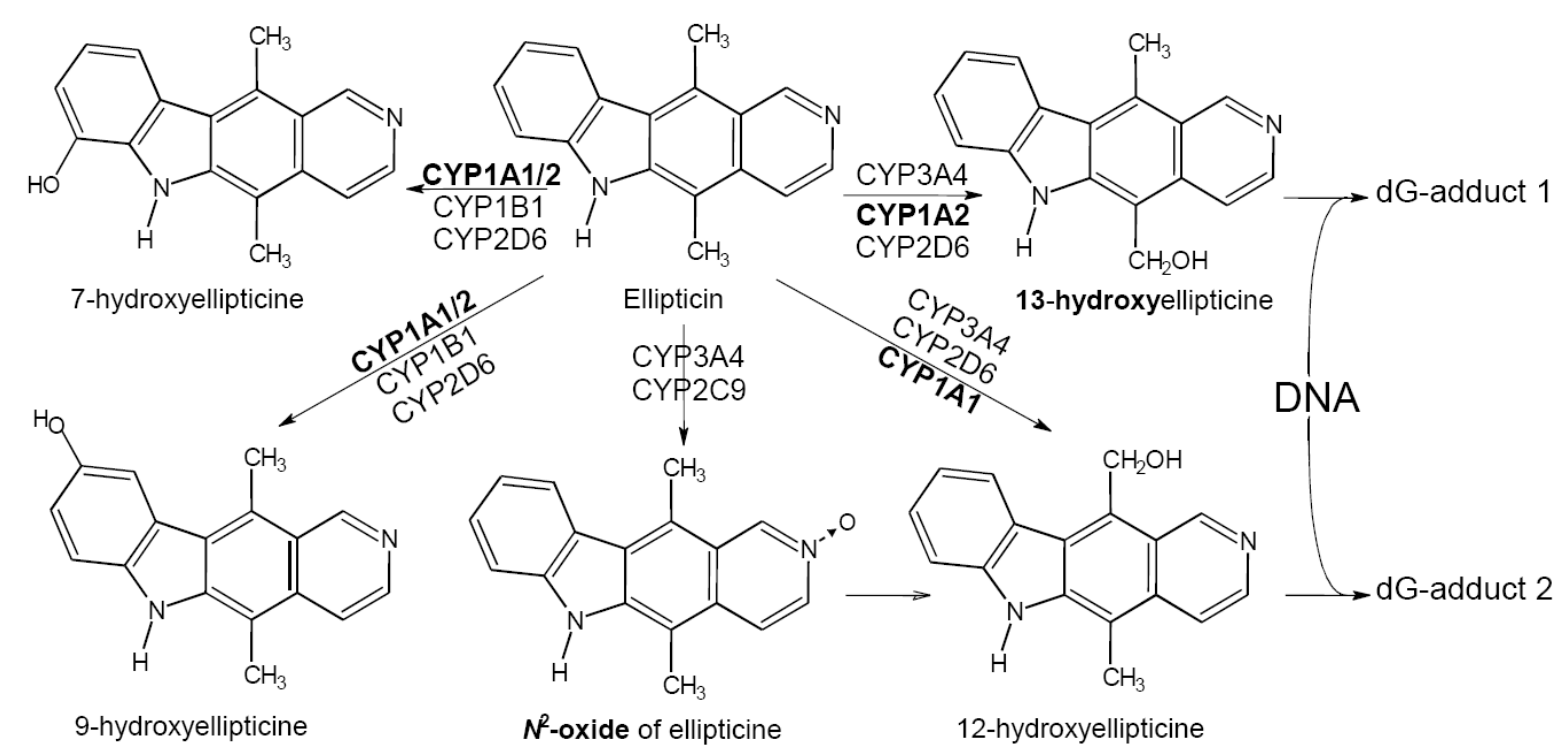

Figure 1. Metabolism and activation of ellipticine (5,11-dimethyl-6H-pyrido[4,3-b]carbazole) by cytochromes P450, 


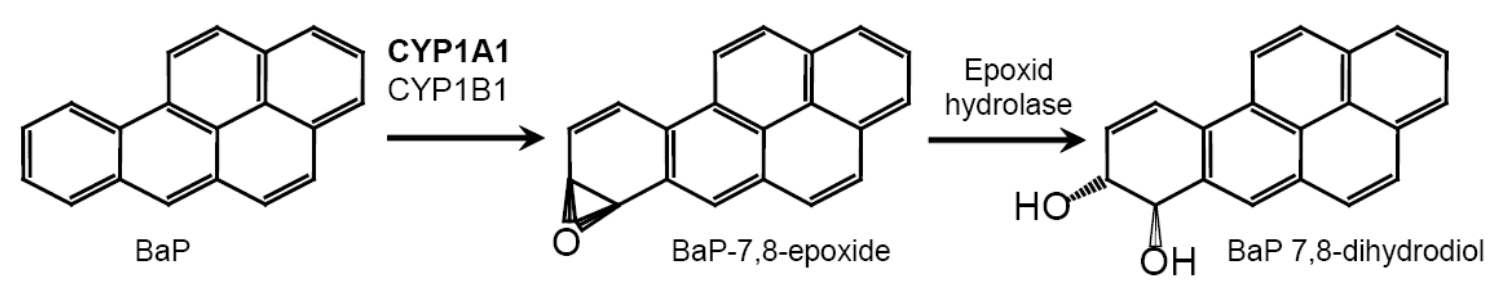

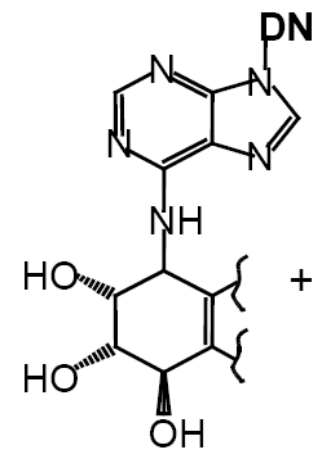

$N^{6}$-adenine (dG-N²-BPDE)

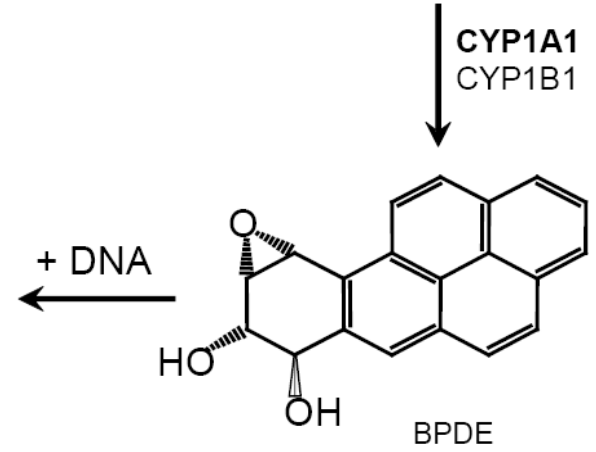

$N^{2}$-guanine (dG-N²-BPDE)

Figure 2. Metabolic activation and DNA adduct formation by benzo(a)pyrene: The typical 3-step activation process with contribution of CYP1A1 or CYP1B1 and epoxide hydrolase leads to the formation of the ultimately reactive species, benzo[a]pyrene-7,8-dihydrodiol-9,10-epoxide (BPDE) that can react with DNA, forming adducts preferentially at guanine residues.

Here, we summarize the results obtained with rats and mice previously, and present novel data obtained with these animal models. Such a study is necessary to evaluate results found till the present time and to suggest which further studies are necessary to improve our knowledge in this field.

\section{Material and Methods}

\section{Animal models}

The study was conducted in accordance with the Regulations for the Care and Use of Laboratory Animals (311/1997, Ministry of Agriculture, Czech Republic), which complies with Declaration of Helsinki. Rats, the animal model found to be suitable to mimic the fate of ellipticine in humans (Stiborová et al., 2003a; 2006), and two mouse lines, namely,.(i) „Hepatic Reductase Null“ (HRN $\left.{ }^{\mathrm{Tm}}\right)$ mice based on a C57BL/6 background (CXR Bioscience Ltd, Dundee, UK), in which NADPH:cytochrome $\mathrm{P} 450$ reductase (POR) is specifically deleted in the liver (Porlox/lox $\left.+\mathrm{Cre}^{\mathrm{ALB}}\right)$ (Henderson et al., 2003, 2006) and (ii) mice homozygous for loxP sites at the Por locus (Porlox/lox) as wild-type (WT) mice, were used in this study.

\section{Treatment of animals with ellipticine and benzo(a)pyrene}

Male and female Wistar rats ( 100 g) were treated with a single dose of 4,40 or $80 \mathrm{mg} / \mathrm{kg}$ body weight $(\mathrm{n}=3)$ of ellipticine by intraperitoneal injection as described (Aimová et al., 2007). Ellipticine was dissolved in sunflower oil/dimethyl sulphoxide $(1: 1, \mathrm{v} / \mathrm{v})$ at a concentration of $6 \mathrm{mg} / \mathrm{ml}$, control animals $(n=3)$ received solvent only. The doses of ellipticine used for the treatment of rats are in the range of dosage in human therapy $\left(80-100 \mathrm{mg} / \mathrm{m}^{2}\right)$.

Groups $(n=3)$ of female HRN ${ }^{\mathrm{Tm}}$ and WT mice (3 months old, 25-30 g) were treated intraperitoneally with a single dose of $10 \mathrm{mg}$ ellipticine per $\mathrm{kg}$ body weight as described previously (Stiborová et al., 2008). Ellipticine was administered as $10 \mathrm{mg} / \mathrm{ml}$ solution in distilled $1 \%$ acetic acid, control animals $(\mathrm{n}=3)$ received solvent only.

To evaluate the BaP-mediated induction of CYP1A, groups $(\mathrm{n}=3)$ of $\mathrm{HRN}^{\mathrm{Tm}}$ and WT female mice were treated with $125 \mathrm{mg} \mathrm{BaP}$ per $\mathrm{kg}$ body weight once daily for five days by intraperitoneal injection. BaP was dissolved in corn-oil at a concentration of $12.5 \mathrm{mg} / \mathrm{ml}$, control animals $(n=3)$ received solvent only (Arlt et al., 2008).

\section{Preparation of microsomes and assays}

Microsomes were isolated from pooled rodent livers as described (Stiborová et al., 2003b). Protein concentrations in the microsomal fractions (bicinchoninic acid protein assay with bovine serum albumin as a standard), the activities of hepatic microsomal CYP1A1/2 (7-ethoxyresorufin $O$-deethylation, EROD) and POR (using cytochrome c) as well as the protein levels of these enzymes (Western Blot) were determined as described previously (Stiborová et al., 2003a,b, 2005).

Oxidation of ellipticine by hepatic microsomes. Incubation mixtures contained $50 \mathrm{mM}$ potassium phosphate 
buffer ( $p$ H7.4), NADPH-generating system (1 mM NADP ${ }^{+}$, $10 \mathrm{mM}$ D-glucose 6-phosphate, $1 \mathrm{U} / \mathrm{ml} \mathrm{D}$-glucose 6-phosphate dehydrogenase), $0.2 \mathrm{mg}$ microsomal protein, $10 \mu \mathrm{M}$ ellipticine (dissolved in $5 \mu \mathrm{l}$ methanol) in a final volume of $500 \mu \mathrm{l}$. The reaction was initiated by adding the substrate. After incubation in open glass tubes $\left(37^{\circ} \mathrm{C}, 20 \mathrm{~min}\right)$ the reaction was stopped by adding $100 \mu \mathrm{l}$ of $2 \mathrm{M} \mathrm{NaOH}, 5 \mu \mathrm{l}$ of $1 \mathrm{mM}$ phenacetine in methanol was added as an internal standard. Ellipticine metabolites were extracted twice with ethyl acetate $(2 \times 1 \mathrm{ml})$ and analyzed by HPLC as described (Stiborová et al., 2006; 200ß).

Activation of ellipticine or BaP by hepatic microsomes

Incubation mixtures (final volume of $750 \mu \mathrm{l}$ ) used to asses DNA adduct formation consisted of $50 \mathrm{mM}$ potassium phosphate buffer (pH 7.4), 1 mM NADPH, $0.5 \mathrm{mg}$ of microsomal proteins and $0.5 \mathrm{mg}$ of calf thymus DNA. Incubations were also carried out in the presence of a COX cofactor, $0.1 \mathrm{mM}$ arachidonic acid instead of NADPH, and additionally $5 \mathrm{mM}$ magnesium chloride. The reaction was initiated by adding $0.1 \mathrm{mM}$ ellipticine (dissolved in $7.5 \mu \mathrm{l}$ methanol) or $0.1 \mathrm{mM}$ $\mathrm{BaP}$ (dissolved in $7.5 \mu \mathrm{l}$ dimethyl sulphoxide). Incubations at $37^{\circ} \mathrm{C}$ were carried out for 30 or 90 min with ellipticine or $\mathrm{BaP}$, respectivelly. DNA was isolated from the residual water phase by the phenol/chloroform extraction method as described (Stiborová et al., 2001).

\section{Inhibition studies}

The following chemicals were used to inhibit the activation of ellipticine and $\mathrm{BaP}$ by mouse hepatic microsomes: $\alpha$-naphthoflavone ( $\alpha-\mathrm{NF})$, which inhibits CYP1A1 and 1A2; indomethacin, a selective inhibitor of COX; $\alpha$-lipoic acid $(\alpha-\mathrm{LA})$, which inhibits POR; ellipticine, frequently utilized as competitive inhibitor of CYP1A1 enzyme. Inhibitors were added to incubation mixture in $7.5 \mu \mathrm{l}$ of methanol to yield final concentrations of $0.1 \mathrm{mM}$ and pre-incubated at $37^{\circ} \mathrm{C}$ for 10 min with NADPH prior to adding substrate (ellipticine or $\mathrm{BaP}$ ) and then incubated for as described above. After the incubation, DNA was isolated as described above.

\section{Measurement of DNA adducts}

32P-postlabeling analysis with nuclease P1 enrichment, thin-layer chromatography (TLC) and high performance liquid chromatography (HPLC) of 32P-labelled 3'5'-deoxyribonucleoside bisphosphate adducts with ellipticine were done as reported recently (Stiborová et al., 2001; 2003a; 2004; 2007a). DNA adducts formed by BaP were analyzed
A

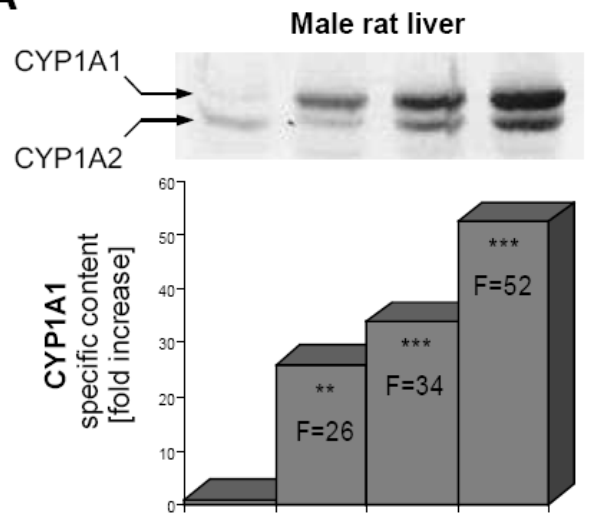

B

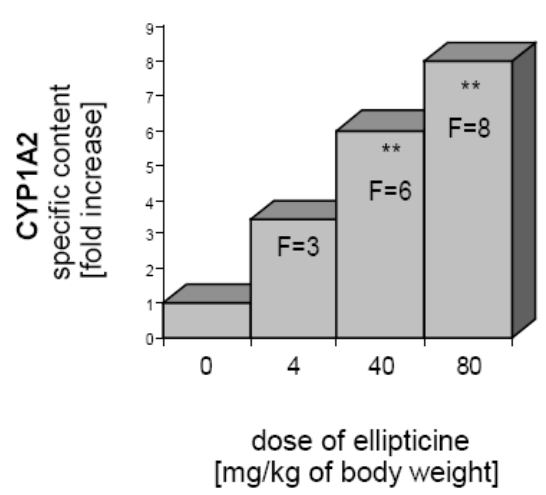

C
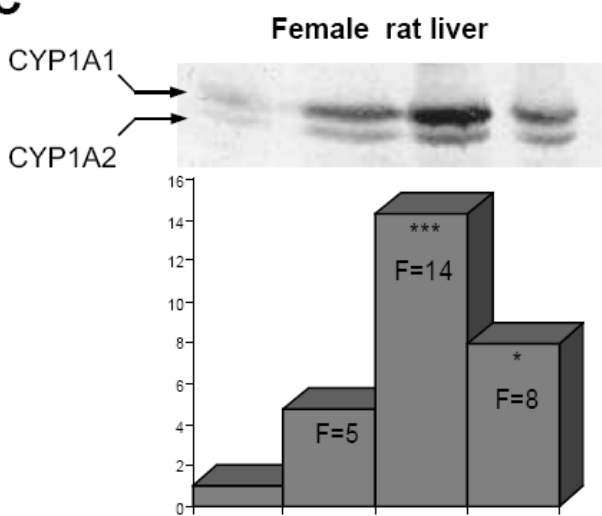

D

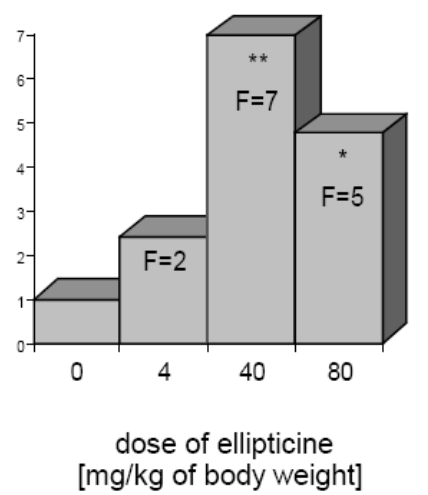

Figure 3. Induction of CYP1A1 $(\mathbf{A}, \mathbf{C})$ and $1 \mathrm{~A} 2(\mathbf{B}, \mathbf{D})$ proteins in livers of male $(\mathbf{A}, \mathbf{B})$ and female $(\mathbf{C}, \mathbf{D})$ rats, uninduced or treated with 4,40 or $80 \mathrm{mg}$ of ellipticine per $\mathrm{kg}$ of body weight. Inset in A and C: immunoblots of microsomal CYP1A1 and 1 A2 from untreated and ellipticine-treated male and female rats, respectively, stained with antibody against rat CYP1A1. Mean values shown in figure represent results obtained from livers of three rats $(n=3), S D<15 \%$. Values significantly different from the control: ${ }^{*} p<0.05,{ }^{* *} p<0.01,{ }^{* * *} p<0.001$. 
analogously, using the ${ }^{32} \mathrm{P}$-postlabeling technique as described previously (Arlt et al., 2008).

\section{Results}

\section{Induction of hepatic CYP1A by ellipticine and BaP}

Ellipticine and BaP induced expression of CYP1A1 and 1A2 proteins, which leads to an increase their enzymatic activities in livers of animal models used in the experiments (rats for ellipticine and mice for BaP) (Figures 3 and 4).

As shown in Figure 3, the induction of CYP1A by ellipticine was dose-dependent. The increase in expression of CYP1A proteins correlated with that in specific CYP1Amediated activity, EROD (Table 1).

In the case of $\mathrm{BaP}$, mouse models, $\mathrm{HRN}^{\mathrm{mm}}$ and its parental WT-line, were utilized for the induction experiments. RRN $^{\mathrm{Tw}}$ mice were found to be more susceptible to BaP-mediated CYP1A induction than the WT mouse line (Figure 4A). Using this model, lacking hepatic POR, we also evaluated whether expression of this enzyme is influenced by treating animals with $\mathrm{BaP}$. Treatment of mice with $\mathrm{BaP}$ led to a moderate increase in expression of hepatic POR in both WT (1.2-fold increase) and $\mathrm{HRN}^{\mathrm{TN}}$ mice (1.4-fold increase).
In spite of POR deficiency, CYP1A activity (EROD) was restored by $\mathrm{BaP}$ treatment in $\mathrm{HRN}^{\mathrm{TM}}$ mice, representing the 73-fold increase in EROD activity in microsomes of uninduced WT mice and $30 \%$ of this activity in BaP-induced WT mice (Figure 4B).

\section{DNA adduct formation in vivo}

In further part of the study, we evaluated the potential of ellipticine and $\mathrm{BaP}$ to induce DNA adduct formation in vivo. Mice were used as models in these experiments. Treatment of individual mouse strains with ellipticine and $\mathrm{BaP}$ resulted in DNA adduct formation (Figure 5-7). The livers of all animal models were the major target organ for DNA adduct formation. Comparative analyses on TLC and HPLC have shown that DNA adduct formation in vivo proceeds via the reactive metabolite BPDE bound to the $N^{2}$ position of guanine (dG-N $\left.{ }^{2}-\mathrm{BPDE}\right)$ for BaP (Figures 2 and 6) and via 13-hydroxy- and 12-hydroxyellipticine in the case of the two major ellipticine-derived DNA adducts (spots 1 and 2 in Figures 1 and 5).

The experiments employing the mouse models helped us to improve our knowledge on the efficiency of CYPs to activate ellipticine and BaP. Levels of ellipticine-derived adducts in livers of $\mathrm{HRN}^{\mathrm{sm}}$ mice (Figure $5 \mathrm{E}$ ) were reduced (by up to
A

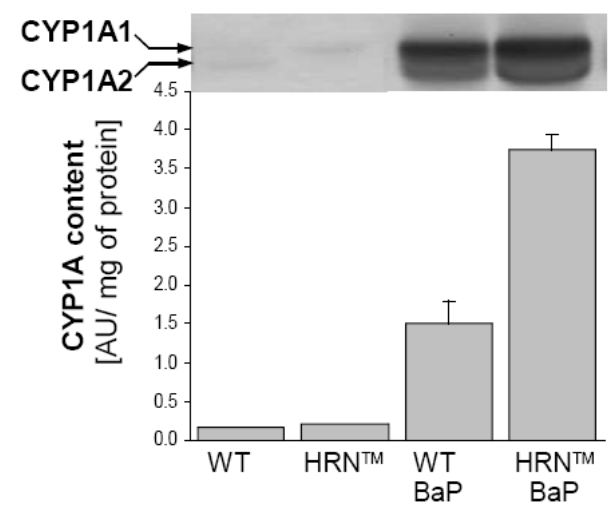

B

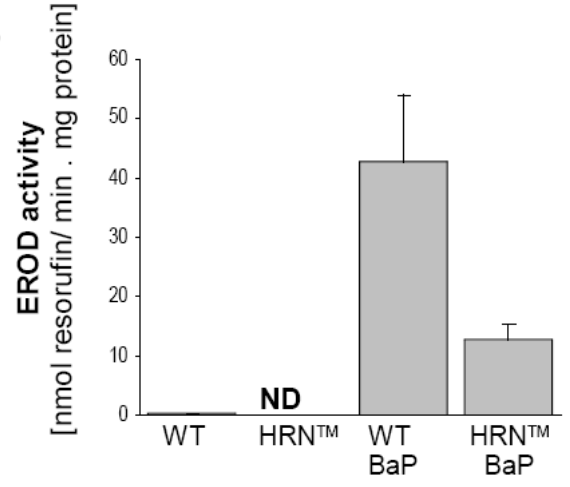

C
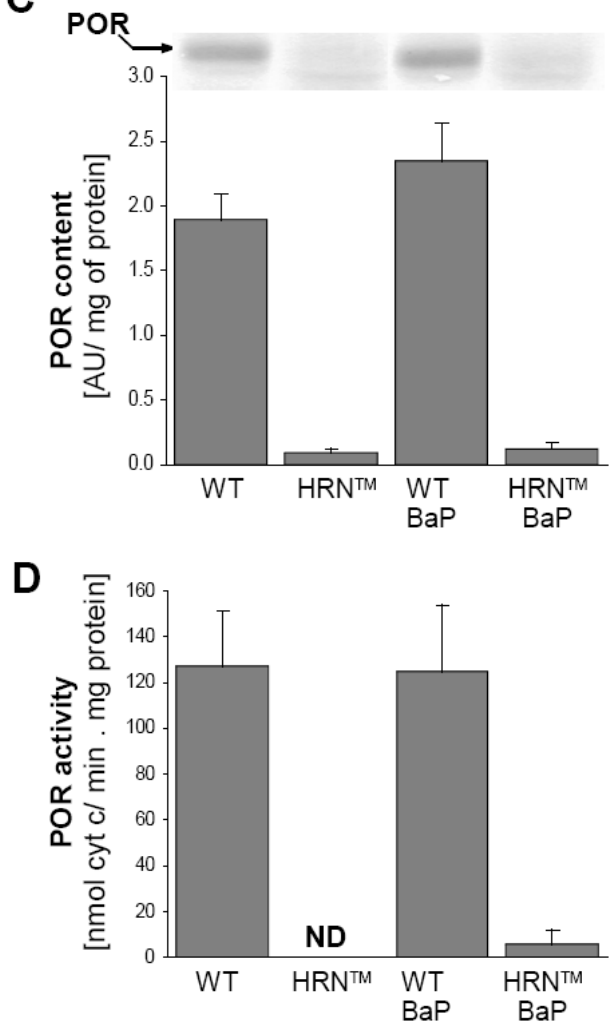

Figure 4. Induction of CYP1A (A,B) and POR (C,D) protein levels $(\mathbf{A}, \mathbf{C})$ and activities (B,D) in livers of female mice with deleted (HRN $\left.{ }^{\top M}\right)$ or intact (WT) liver POR, uninduced or treated (i.p.) with $5 \times 125 \mathrm{mg}$ of BaP per $\mathrm{kg}$ of body weight. Inset in A: immunoblots of microsomal CYP1A1/2 stained with chicken antibody against rat CYP1A1. Inset in C: immunoblots of microsomal POR stained with chicken antibody against rabbit POR. Microsomes were pooled from livers of 3 animals. Mean and SD evaluated from three separate experiments $(n=3)$. ND = not detectable at used conditions. 
$65 \%)$ relative to levels in WT mice (Figure 5D), indicating that POR-mediated CYP enzyme activity is important for the oxidative activation of ellipticine to metabolites generating these adducts.

In contrast to these results, the highest DNA binding of $\mathrm{BaP}$ was observed in livers of $\mathrm{HRN}^{\mathrm{Tm}}$ mice (Figure $6 \mathrm{~A}$ ) which was 6.4-fold $(\mathrm{p}<0.01)$ higher than DNA binding in WT mice (Figure 6B). This unexpectable finding indicates increasing the CYP-mediated activation of BaP by lack of POR in the liver.

\section{Activation of ellipticine and BaP by hepatic microsomes}

In order to further investigate the participation of CYPs in activation of ellipticine and $\mathrm{BaP}$ and which of these enzymes play the major role, the in vitro experiments were carried out. First, incubations of DNA with $\mathrm{BaP}$ and/or ellipticine with microsomes isolated from livers of $\mathrm{HRN}^{\mathrm{rw}}$ and WT mice, untreated or treated with $\mathrm{BaP}$, were performed. In all cases, the patterns of DNA adducts formed by ellipticine and $\mathrm{BaP}$ in these experiments were essentially the same as those found in vivo (Figures 5 and 6 ), generated by the pathways shown in Figures 1 and 2 . The identity of adducts formed by both compounds in vitro with those formed in vivo was proved using the TLC and HPLC-cochromatography (data not shown).

Hepatic microsomes isolated from animals treated with ellipticine or $\mathrm{BaP}$ were always more effective to form ellipticine- and BaP-derived DNA adducts (Figures 5 and 7) than microsomes from untreated animals. A decrease in levels of ellipticine-derived adducts formed by microsomes from $\mathrm{HRN}^{\mathrm{Tm}}$ mice compared with WT-mice (Figure 7C-D) correlated with almost 2-fold lower levels of 13-hydroxyand 12-hydroxyellipticine, the metabolites generating the ellipticine-DNA adducts, formed by these microsomes (Stiborová et al., 2008).

NADPH-dependent activation of BaP was even 4- to 7-fold lower in $\mathrm{HRN}^{\mathrm{rm}}$ compared to WT mouse microsomes (Figure 7A-B). The study investigating the pattern of BaP metabolites formed by microsomes from livers of all mouse groups (control HRN ${ }^{\mathrm{mm}}$ and WT-mice as well as these mice treated with $\mathrm{BaP}$ ), which might explain this feature is under way in our laboratory. Preliminary results suggest that the
Table 1. Specific CYP1A activity (EROD) in hepatic microsomes of control and ellipticine-treated rats.

\begin{tabular}{l|cc|cc}
\hline $\begin{array}{l}\text { CYP } \\
\text { activity }\end{array}$ & \multicolumn{2}{|c|}{ Control rats } & \multicolumn{2}{|c|}{ Ellipticine-treated rats } \\
\hline & Male & Female & Male & Female \\
\hline EROD & $80.7 \pm 2.0$ & $225.8 \pm 50.5$ & $551.4 \pm 92.2$ & $1737.5 \pm 161.3$ \\
\hline
\end{tabular}

a Each value (pmol of reaction product/min/nmol CYP) represents the mean \pm standard deviation of data from two rats in two separate assays $(n=4)$.

treatment of WT mice with BaP influenced only the relative metabolites ratio instead of the total efficiency of $\mathrm{BaP}$ metabolite formation.

In all model systems, the use of POR-inhibitor ( $\alpha$-lipoic acid), CYP1A-inhibitors ( $\alpha$-naphthoflavone, ellipticine) and a CYP3A-inhibitor (ketoconazole) decreased the DNA-adduct formation by both compounds (Figure 7). These results suggest that even very low levels of the POR enzyme in livers of $\mathrm{HRN}^{\mathrm{sm}}$ mice are still sufficient to mediate CYP-catalyzed activation reactions.

In order to determine which CYPs and/or other enzymes are responsible for DNA adduct formation by both compounds, modulation of microsome-mediated activation with cofactors and inhibitors of individual enzymes was utilized. Addition of NADH, a cofactor of microsomal $\mathrm{NADH}$ :cytochrome $\mathrm{b}_{5}$ reductase, acting as second electron donor for CYP-dependent systems, lowered the difference between $\mathrm{HRN}^{\mathrm{Tm}}$ and WT microsomal BaP-activation (Figure 7A-B). Arachidonic acid (AA), a cofactor of COXdependent oxidation, was effective to activate ellipticine to species forming DNA adducts (Figure $7 \mathrm{C}-\mathrm{D}$ ), but not to mediate the BaP-DNA adduct formation (Figure 7A-B). On the contrary, an inhibitor of COX, indomethacin (IM) decreases $\mathrm{BaP}$ activation in incubations with hepatic microsomes from BaP-treated $\mathrm{HRN}^{\mathrm{TM}}$ mice, by $30-40 \%$ (Figure7B). These results may indicate the participation of COX in activation of both compounds, but with lower efficiency than CYPs.

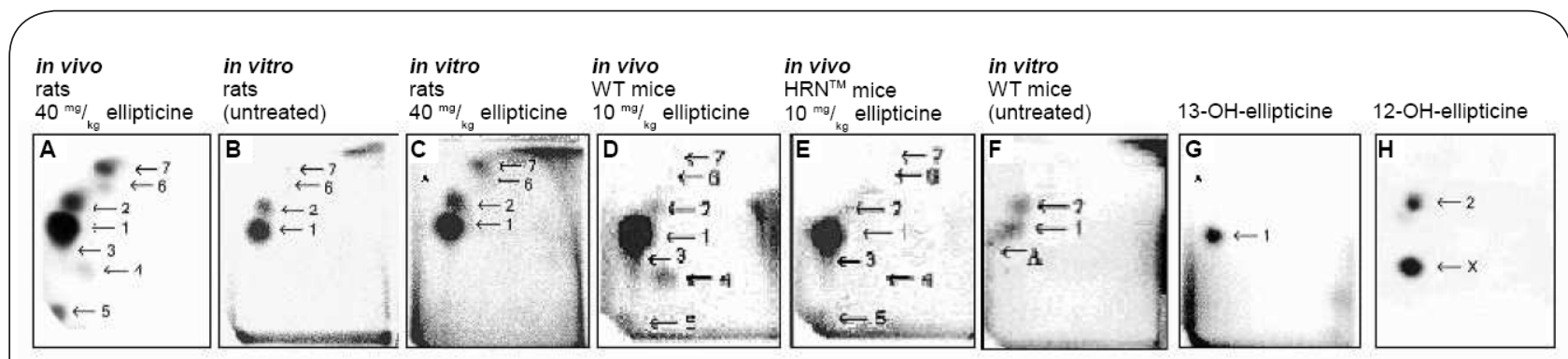

Figure 5. Autoradiographic profile of ellipticine-derived DNA adducts:

- in vivo in liver DNA of ellipticine-treated rats $(\mathbf{A}) ; H_{R N}{ }^{\mathrm{TM}}(\mathbf{D})$ and WT $(\mathbf{E})$ mice.

- in vitro in calf thymus DNA after ellipticine activation with hepatic microsomes of untreated (B)

and ellipticine-treated $(\mathbf{C})$ male rats and wild-type mice $(\mathbf{F})$

- in vitro in calf thymus DNA reacted directly with ellipticine metabolites 13-hydroxyellipticine (G) or 12-hydroxyellipticine (H) (without enzymatic activation). Analyses were performed by the nuclease P1 version of the ${ }^{32}$ P-postlabelling assay. 


\section{in vivo $\mathrm{HRN}^{\mathrm{TM}}$ mice}

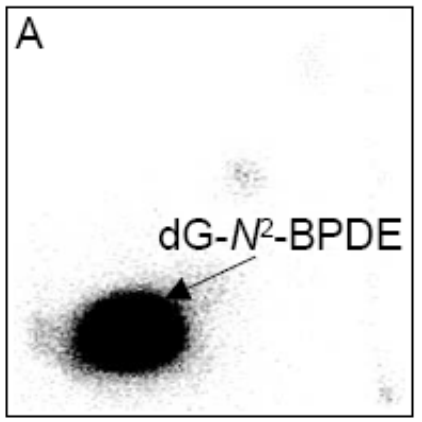

\section{in vivo}

WT mice

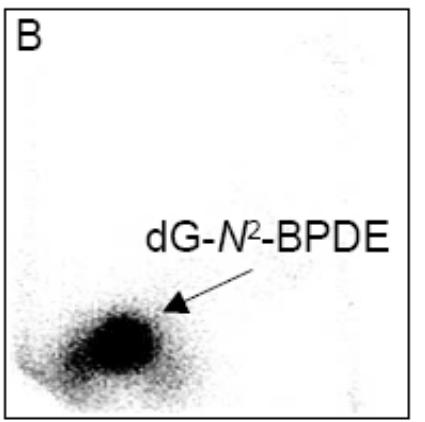

BPDE

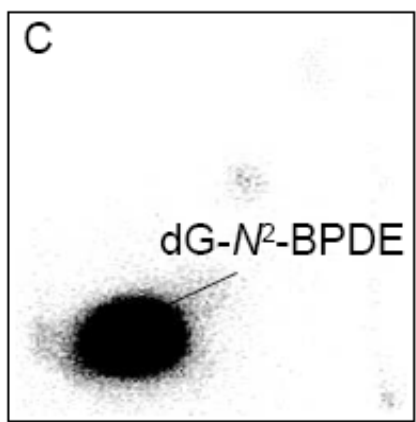

Figure 6. Autoradiographic profiles of BaP-derived DNA adducts in vivo in liver DNA of HRN ${ }^{\mathrm{TM}}(\mathbf{A})$ and WT (B) mice treated with 5 times 125 mg of BaP/kg body weight and in vitro in salmon testis DNA modified with BPDE (C) (without enzymatic activation). Analyses were performed by the nuclease P1 version of the ${ }^{32}$ P-postlabelling assay.

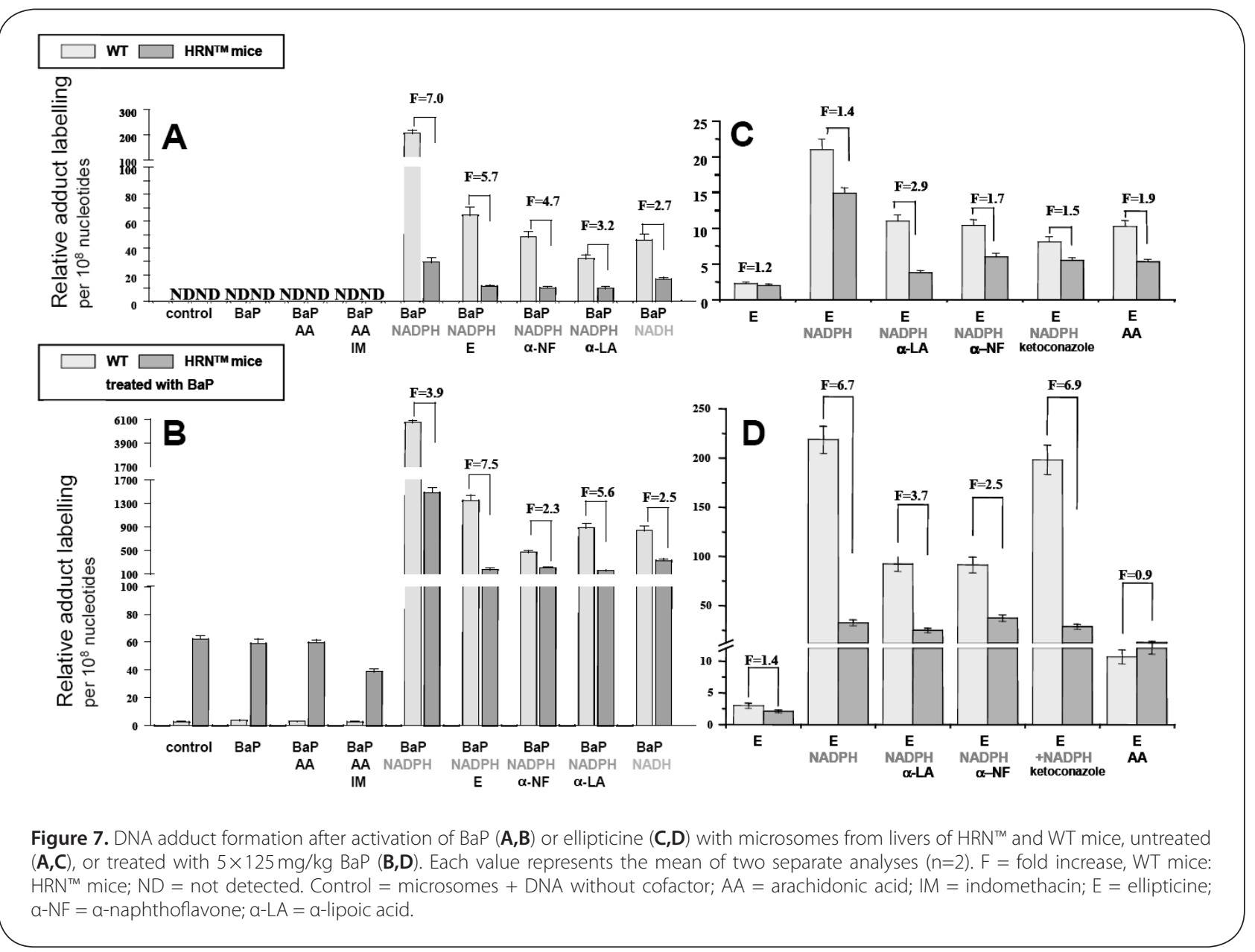

\section{Discussion}

As shown in several studies published previously, ellipticine and $\mathrm{BaP}$ are two xenobiotics that react with DNA forming covalent DNA adducts (for a summary, see Stiborová et al., 2006b; Arlt et al., 2008). This genotoxic effect is mediated by their CYP-mediated metabolism. Although the CYP enzymes activating ellipticine and $\mathrm{BaP}$ to species binding to DNA in vitro have already been identified (Baird et al., 2005; Stiborová et al., 2001; 2003a; 2004; 2006a; 2008; Kotrbová et al., 2006; Arlt et al., 2008), the knowledge on the real impact of these CYPs on the activation of these compounds in vivo is limited. Likewise, the effects of repeated exposure of organisms to these compounds on enzyme-mediated activation process are scarce. 
To evaluate the contribution and importance of hepatic $\mathrm{CYP}$ enzymes to the activation of ellipticine and $\mathrm{BaP}$ in vivo, we have used in our former and present studies the rats and especially the HRN ${ }^{\mathrm{sw}}$ mice, lacking POR and thus also POR-mediated CYP enzyme activity in the liver (Henderson et al., 2003; 2006), as model organisms. The use of the HRN ${ }^{\mathrm{mm}}$ mouse model has already contributed to resolve the in vivo enzymatic activation of several environmental toxicants, including carcinogenic 3-nitrobenzanthrone, activated by cytosolic nitroreductases rather than microsomal POR, and its reductive metabolite 3-aminobenzanthrone (Svobodová et al., 2007), whose activation is CYP-dependent (Arlt et al., 2003, 2004, 2005, 2006).

Ellipticine and $\mathrm{BaP}$ significantly induced expressions of CYP1A1 and 1A2 proteins as well as their enzymatic activity such as EROD in rodent livers. The CYP1A induction resulted in a significant increase in levels of ellipticine- and $\mathrm{BaP}$-derived DNA adducts in vitro, in incubations of ellipticine or $\mathrm{BaP}$ with microsomes from rats treated with these compounds than in incubations with control microsomes. This is an important finding, because CYP1A enzymes are essential for ellipticine and $\mathrm{BaP}$ metabolism. Indeed, the importance of POR-mediated CYP1A1 activation of both compounds in vitro was confirmed by inhibition studies using a specific POR inhibitor, $\alpha$-lipoic acid, and a CYP1A inhibitor, $\alpha$-naphtoflavone.

Analogously to the results found in vitro, the levels of two major DNA adducts in animals treated with ellipticine were significantly decreased in liver DNA of HRN ${ }^{\mathrm{ma}}$ mice, confirming the importance of CYP enzymes in ellipticine activation in this organ in vivo. Inhibition of NADPHdependent ellipticine activation in hepatic microsomes of $\mathrm{HRN}^{\mathrm{su}}$ and WT mice by $\alpha-\mathrm{NF}$ and ketoconazole suggests that CYPs of $1 \mathrm{~A}$ and $3 \mathrm{~A}$ subfamilies play a major role in this process in mice livers, analogously to human and rat livers (Stiborová et al., 2001; 2003a, b). Nevertheless, the reduction of DNA adduct formation in the liver of $\mathrm{HRN}^{\mathrm{Tm}}$ mice was not absolute, being $\sim 65 \%$. Likewise, the decrease in levels of these two ellipticine-DNA adducts in hepatic microsomes of $\mathrm{HRN}^{\mathrm{Tm}}$ mice caused by inhibitors of POR and CYPs was between $40-65 \%$. These results suggest that other enzymes may also activate ellipticine in mice livers. A potential of arachidonic acid, a cofactor of COX enzymes, to increase the formation of these adducts in mice hepatic microsomes in vitro indicate that COX might be one of such enzymes.

On the contrary, BaP-induced DNA adduct formation in vivo was significantly increased in liver of $\mathrm{HRN}^{\mathrm{Tw}}$ compared to WT mice, indicating that the real function of PORmediated CYPs reactions is the BaP detoxification. Taken our results together with those from the CYP1-deletion studies (Uno et al., 2004, 2006), there is a remarkable discrepancy between the in vivo DNA adduct levels and in vitro $\mathrm{BaP}$ activation, which is still very difficult to explain. Although hepatic CYP enzyme activity has been essentially inactivated by the conditional deletion of hepatic POR, in non-parenchymal liver cells, the POR deletion may be incomplete. This residual POR activity, in combination with more pronounced induction of CYP enzymes (and probably also by induction of POR) in livers of $\mathrm{HRN}^{\mathrm{Tm}}$ mice liver may explain these in vitro findings. Another explanation could be the induction of other metabolizing enzymes.

Taken together, these results show evidence of the crucial role of CYP1A enzymes in ellipticine and $\mathrm{BaP}$ genotoxic effect in vivo. By inducing CYP1A1/2, both compounds modulate their either pharmacological (ellipticine) and/or genotoxic potential (both chemicals); ellipticine increases its own metabolism leading to enhanced formation of reactive species forming DNA adducts and $\mathrm{BaP}$ enhances its detoxification process.

\section{REFERENCES}

Aimová D, Svobodová L, Kotrbová V, Mrázová B, Hodek P, Hudecek J, Václavíková R, Frei E, Stiborová M (2007) The anticancer drug ellipticine is a potent inducer of rat cytochromes P450 $1 \mathrm{~A} 1$ and $1 \mathrm{~A} 2$, thereby modulating its own metabolism. Drug Metab Dispos 35: 1926-34.

Arlt VM, Henderson CJ, Wolf CR, Schmeiser HH, Phillips DH, Stiborova M (2006) Bioactivation of 3-aminobenzanthrone, a human metabolite of the environmental pollutant 3-nitrobenzanthrone: evidence for DNA adduct formation mediated by cytochrome P450 enzymes and peroxidases. Cancer Lett 234: 220-31.

Arlt VM, Hewer A, Sorg BL, Schmeiser HH, Phillips DH, Stiborova M (2004) 3-Aminobenzanthrone, a human metabolite of the environmental pollutant 3-nitrobenzanthrone, forms DNA adducts after metabolic activation by human and rat liver microsomes: evidence for activation by cytochrome P450 1A1 and P450 1A2. Chem Res Toxicol 17: 1092-101.

Arlt VM, Stiborova M, Henderson CJ, Osborne MR, Bieler CA, Frei E, Martinek V, Sopko B, Wolf CR, Schmeiser HH, Phillips DH (2005) Environmental pollutant and potent mutagen 3-nitrobenzanthrone forms DNA adducts after reduction by $\mathrm{NAD}(\mathrm{P}) \mathrm{H}$ : quinone oxidoreductase and conjugation by acetyltransferases and sulfotransferases in human hepatic cytosols. Cancer Res 65: 2644-52.

Arlt VM, Stiborová M, Henderson CJ, Thiemann M, Frei E, Aimová D, Singh R, Gamboa da Costa G, Schmitz OJ, Farmer PB, Wolf CR, Phillips DH (2008) Metabolic activation of benzo[a]pyrene in vitro by hepatic cytochrome P450 contrasts with detoxification in vivo: experiments with hepatic cytochrome P450 reductase null mice. Carcinogenesis 29 : 656-65.

Arlt VM, Stiborova M, Hewer A, Schmeiser HH, Phillips DH (2003) Human enzymes involved in the metabolic activation of the environmental contaminant 3-nitrobenzanthrone: evidence for reductive activation by human NADPH: cytochrome P450 reductase. Cancer Res 63: 2752-61.

Baird WM, Hooven LA, Mahadevan B (2005) Carcinogenic polycyclic aromatic hydrocarbon-DNA adducts and mechanism of action. Environ Mol Mutagen 45: 106-14.

Bořek-Dohalská L, Frei E, Stiborová M (2004) DNA adduct formation by the anticancer drug ellipticine and its hydroxy derivatives in human breast adenocarcinoma MCF-7 cells. Collect Czech Chem Commun 69 603-615.

Frei E, Bieler CA, Arlt VM, Wiessler M, Stiborová M (2002) Covalent binding of the anticancer drug ellipticine to DNA in V79 cells transfected with human cytochrome P450 enzymes. Biochem Pharmacol 64: 289-95.

Henderson CJ, Otto DM, Carrie D, Magnuson MA, McLaren AW, Rosewell I, Wolf CR (2003) Inactivation of the hepatic cytochrome P450 system by conditional deletion of hepatic cytochrome $\mathrm{P} 450$ reductase. J Biol Chem 278: 13480-6.

Henderson CJ, Pass GJ, Wolf CR (2006) The hepatic cytochrome P450 reductase null mouse as a tool to identify a successful candidate entity. Toxicology letters 162: 111-7.

IARC Monogr Eval Carcinog Risk Chem Hum (1983) Polynuclear Aromatic Compounds 32, 211.

Kotrbová V, Aimová D, Březinová A, Janouchová K, Poljaková J, Hodek P, Frei E, Stiborová M (2006) Cytochromes P450 reconstituted with NADPH: P450 reductase mimic the activating and detoxicating metabolism of the anticancer drug ellipticine in microsomes. Neuro Endocrinol Lett 27(Suppl. 2): 18-20. 
Kouri RE, Salerno RA, Whitmire CE (1973) Relationships between aryl hydrocarbon hydroxylase inducibility and sensitivity to chemically induced subcutaneous sarcomas in various strains of mice. J Natl Cancer Inst 50: 363-8.

Phillips DH (1999) Polycyclic aromatic hydrocarbons in the diet. Mutat Res 443: 139-47.

Phillips DH (2002) Smoking-related DNA and protein adducts in human tissues Carcinogenesis 23: 1979-2004.

Poljaková J, Dračínský M, Frei E, Hudeček J Stiborová, M (2006) The effect of $\mathrm{pH}$ on peroxidase-mediated oxidation of and DNA-adduct formation by ellipticine. Collect. Czech. Chem. Commun. 71: 1169-1185.

Poljaková J, Frei E, Gomez JE, Aimová D, Eckschlager T, Hraběta J, Stiborová M (2007) DNA adduct formation by the anticancer drug ellipticine in human leukemia HL-60 and CCRF-CEM cells. Cancer Lett 252: 270-9.

Stiborová M, Arlt VM, Henderson CJ, Wolf CR, Kotrbová V, Moserová M, Hudecek J, Phillips DH, Frei E.(2008) Role of hepatic cytochromes P450 in bioactivation of the anticancer drug ellipticine: studies with the hepatic NADPH: cytochrome P450 reductase null mouse. Toxicol Appl Pharmacol 226: 318-27.

Stiborová M, Bieler CA, Wiessler M, Frei E (2001) The anticancer agent ellipticine on activation by cytochrome P450 forms covalent DNA adducts. Biochem Pharmacol 62: 675-84

Stiborová M, Bořek-Dohalská L, Aimová D, Kotrbová V, Kukačková K, Janouchová K, Rupertová M, Ryšlavá H, Hudeček J, Frei E (2006a) Oxidation pattern of the anticancer drug ellipticine by hepatic microsomes - Similarity between human and rat systems. Gen Physiol Biophys 25 : 245-261.

Stiborová M, Breuer A, Aimová D, Stiborová-Rupertová M, Wiessler M, Frei E (2003a) DNA adduct formation by the anticancer drug ellipticine in rats determined by 32P-postlabeling. Int J Cancer 107: 885-890.

Stiborová M, Martínek V, Rýdlová H, Koblas T, Hodek P (2005) Expression of cytochrome P450 1A1 and its contribution to oxidation of a potential human carcinogen 1-phenylazo-2-naphthol (Sudan I) in human livers. Cancer Lett 220: 145-154.
Stiborová M, Poljaková J, Ryšlavá H, Dračínský M, Eckschlager T, Frei E (2007a) Mammalian peroxidases activate anticancer drug ellipticine to intermediates forming deoxyguanosine adducts in DNA identica to those found in vivo and generated from 12-hydroxyellipticine and 13-hydroxyellipticine. Int J Cancer 120: 243-251.

Stiborová M, Rupertová M, Aimová D, Ryšlavá H, Frei E (2007b) Formation and persistence of DNA adducts of anticancer drug ellipticine in rats. Toxicology 236: 50-60.

Stiborová M, Rupertová M, Schmeiser HH, Frei E (2006b) Molecular mechanism of antineoplastic action of an anticancer drug ellipticine. Biomed Pap 150: 13-23.

Stiborová M, Sejbal J, Bořek-Dohalská L, Aimová D, Poljaková J, Forsterová K, Rupertová M, Wiesner J, Hudeček J, Wiessler M, Frei E (2004) The anticancer drug ellipticine forms covalent DNA adducts, mediated by human cytochromes $\mathrm{P} 450$, through metabolism to 13-hydroxyellipticine and ellipticine $\mathrm{N}^{2}$-oxide. Cancer Res 64: 8374-8380.

Stiborová M, Stiborová-Rupertová M, Bořek-Dohalská L, Wiessler M, Frei E (2003b) Rat microsomes activating the anticancer drug ellipticine to species covalently binding to deoxyguanosine in DNA are a suitable model mimicking ellipticine bioactivation in humans. Chem Res Toxicol 16: 38-47.

Svobodová M Šístková J, Dračínská H, Hudeček J, Hodek P, Schmeiser HH, Arlt VM, Frei E, Stiborová M (2007) Reductive activation of environmental pollutants 3-nitrobenzanthrone and 2-nitrobenzanthrone. Che. Listy 100: $s 277-s 279$.

Uno S, Dalton TP, Derkenne S, Curran CP, Miller ML, Shertzer HG, Nebert DW (2004) Oral exposure to benzo[a]pyrene in the mouse: detoxication by inducible cytochrome P450 is more important than metabolic activation. Mol Pharmaco/ 65: 1225-37.

Uno S, Dalton TP, Dragin N, Curran CP, Derkenne S, Miller ML, Shertzer HG, Gonzalez FJ, Nebert DW (2006) Oral benzo[a]pyrene in Cyp1 knockout mouse lines: CYP1A1 important in detoxication, CYP1B1 metabolism required for immune damage independent of total-body burden and clearance rate. Mol Pharmaco/ 69: 1103-14. 